\title{
Toward Performance-based Politics: Swing Voters in South Africa's 2016 Local Elections
}

\author{
Adam S. Harris ${ }^{1}$ \\ Department of Political Science, University College London, London, UK \\ 29/30 Tavistock Square \\ WC1H $9 Q U$ \\ adam.s.harris@ucl.ac.uk
}

1 The author would like to thank the Program on Governance and Local Development (GLD) at the University of Gothenburg for funding the project. 


\section{Toward Performance-based Politics: Swing Voters in South Africa's 2016 Local Elections}

Who are the swing voters in South Africa's elections? This study is among the first to systematically investigate the correlates of the swing vote in South Africa. The paper argues that race, cohort, performance, and partisan networks influence the likelihood that an individual is a swing voter. To investigate these arguments, this study uses original exit poll survey data from South Africa's 2016 local elections. The results indicate that swing voters are those who have weaker racial identities, weaker attachments to their racial group's party, are born free, have lower assessments of ANC performance, and have fewer friends and family who support their preferred party. The paper also predicts what drives swing voters to support a certain party. The results have key implications for race and identity-based voting in South Africa and dominant regimes across the continent and suggests that South Africa's elections are not clearly a racial census.

Keywords: swing voters; South Africa; race; democratic accountability; elections

Word Count: 9,998 


\section{Introduction}

South Africa's 2016 local elections were the most competitive the country has seen in its 22 years of democracy. The African National Congress (ANC) was under electoral threat due, in large part, to its many corruption scandals. As a result, the ANC suffered its greatest loss since 1994 by only securing $53.9 \%$ of the vote; the first time it has slipped below $60 \%$. More importantly, the ANC, for the first time, lost majorities in key municipal governments including Tshwane, which includes the capital, Pretoria; Johannesburg, the economic powerhouse of the country; and Nelson Mandela Bay. While the ANC was clearly under threat, in the run-up to the elections, it was entirely unclear how well the ANC would do and if the main opposition party, the Democratic Alliance (DA), was realistic in its goals to gain control of any of these three municipalities. Would people in these municipalities punish the ANC for corruption or lack of service delivery? Which voters would do so? These questions are still largely unanswered. While theories have been proposed and explanations presented (see, Paret 2018), no study has sought to empirically investigate who the swing voters are that led to the ANC's historic losses in 2016. This paper seeks to do precisely that using original, exit poll survey data from Tshwane municipality.

The case of the 2016 elections is also important because it is a possible signal that democracy is strengthening in South Africa. The democratic transfer of power is key to democratic consolidation (Przeworski 2015): without a threat of being removed from office, a dominant party regime, such as the ANC in South Africa (Giliomee and Simkins 1999), is only weakly democratic because elections have a limited ability to hold the ANC to account (Harris and Hern 2018) as is evidenced by the extent of corruption and state capture in the ANC government. The 2016 local elections suggest a first real chink in the 
ANC's electoral dominance armor, and it is important to understand what drove this key change. Further, as the ANC loses more support, the DA diversifies its support base (Grootes 2013), and voters consider policy, performance, and other non-racial factors, the limits to the racial census hypothesis in South Africa become evident (Habib and Naidu 1999, Habib and Naidu 2006, Everatt 2016). However, scholars have not explicitly investigated how race influences swing voters. Therefore, this paper seeks to further the critique of the racial census hypothesis by investigating the relative importance of race driving the swing vote. By understanding which voters are moving away from the ANC, scholars are able to understand how likely transfers of power are at the national level and to understand if the 2016 elections do in fact represent a move away from race-based politics (Grootes 2016). ${ }^{2}$ These results also have important implications for understanding voter behavior in dominant party regimes and for understanding what types of voters are swing in Africa, which is addressed in the conclusion.

Specifically, the study hypothesizes the degree to which racial, partisan, generational, and party performance considerations predict swing voter status and the party that swing voters are likely to support. The study finds that while racial group membership itself does not predict swing voter status or the party a swing voter will support, identifying primarily in racial terms does make one less likely to be a swing voter, less likely to vote for the DA, and more likely to vote for the EFF (Economic Freedom Fighters). The results indicate that swing voters in the 2016 elections are those who have weaker racial identities,

\footnotetext{
2 The paper does assume, in line with Przeworski's (2015) contention, that a transfer of power is an indicator of a strong democracy. Further in the South African context, this assumption suggests that the erosion of ANC electoral support and thus more black swing voters will strengthen democracy.
} 
weaker attachments to their racial group's party, are born free $^{3}$, have lower assessments of ANC performance, and have fewer friends and family who support their preferred party. In addition, closeness to the ANC prevents black voters from swinging toward the EFF, and swing voters are more likely to support the party they view as having a stronger performance record. These results suggest the existence of a sophisticated set of swing voters and provides systematic evidence that swing voters in South Africa are moving beyond racial politics.

To investigate the drivers of swing voting and establish a profile of swing voters in South Africa's 2016 local elections, I use original exit poll survey data from Tshwane Municipality. Tshwane Municipality, while only one municipality, was chosen because of its high but still uncertain probability of swinging away from the ANC in the run-up to the 2016 election. It was also chosen because in many instances it represents a microcosm of South African society, which helps maximize generalizability. This unique dataset allows us to understand why Tshwane flipped from the ANC to the DA and the EFF. This data also allows scholars to build on past research that seeks to understand the individual-level drivers of vote choice in South Africa (Paret 2018). The paper proceeds as follows. The next section presents a definition and theory of swing voters. I then present the survey data and empirical strategy followed by the results. The final section concludes.

\section{Identifying and Theorizing Swing Voters}

I follow Mayer (2007) in defining swing voters as those who are the most susceptible to persuasion because they are not fully committed to a party: swing voters are more up for

\footnotetext{
${ }^{3}$ The term "born free" is contested with some preferring "post-apartheid generation"; however, I use the former term as this is the term most used in the academic literature.
} 
grabs. Therefore, both theoretically and empirically swing voters in this study are those voters whose preferences change between elections. There exists a debate regarding the definition of swing voters (see Dimock et al (2008) for alternative definitions); however, this study relies on Mayer's (2007) definition as it is simpler and more straight forward than the alternatives.

The study of swing voters has a long tradition in the American context in which scholars have sought to determine the demographic profile of swing voters, with limited success (Mayer and Teixeira 2008). However, scholars have found that in the US context, swing voters are less partisan (Mayer 2008), are less educated and have lower incomes (Dimock et al 2008), and are less interested, less informed, less involved, and less politically motivated (Shaw 2008, Zaller 2003). Cross-nationally, economic performance, the incumbent's personality, and the clarity of responsibility could be factors that cause voters to swing (Powell and Whitten 1993). Recent research in Africa has found that public goods, clientelism, education, urban residence, and the presence of a co-ethnic candidate can but may not always determine swing voter status (Ferree et al 2009, Weghorst and Lindberg 2013, Horowitz 2017).

The literature on Africa that seeks to identify swing voters, has primarily focused on the role of ethnicity. A large body of research has argued that voters in Africa prefer coethnic candidates either because they expect politicians to favor their co-ethnics once in office (rational choice voting, see Posner 2005) or because they gain a psychic benefit (sociological voting, see Green et al 2002) from seeing one of their own in a position of power (e.g. Horowitz 1985, Chandra 2004, Posner 2005, Carlson 2015). Given this coethnic framework, it might be expected that individuals from ethnic groups that are 
represented by ethnically-based parties will be less persuadable and therefore less likely to be swing voters. Meanwhile, those who do not have a co-ethnic candidate will be more likely to be swing voters in Africa's ethnically charged elections. In Kenya, but not in Ghana, this seems to be the case (Horowitz 2017, Weghorst and Lindberg 2013). The precise role of social group identities in determining who is and is not a swing voter is thus not entirely clear. This study seeks to add to this debate by illuminating how identities influence swing voter status. In addition to social identity, this study investigates the role of two key additional demographic characteristics: partisanship and cohort effects.

First, the role of race in South Africa's elections has been well documented in academic research by the strong tendencies of black and white citizens to support the ANC and DA, respectively (Jung 2001, Ferree 2011, Schulz-Herzenberg 2014, de Kadt 2017). More concretely, in the most recent Afrobarometer survey (Round 7, 2016/18), 56\% of black and $57 \%$ of white voters indicated they would vote for the ANC and DA, respectively. While race does tend to correlate with vote choice, that correlation is far from perfect, which indicates the need for this study to further question the racial census characterization of South Africa's elections. Clearly, race is not the sole or most important driver of vote choice for many voters in South Africa's elections (Eldridge and Seekings 1996, Mattes and Piombo 2001, Paret 2018). While race does highly correlate with party preferences, the literature on racial (as well as ethnic) voting suggests that those without a party that represents their group may be more likely to be swing voters because they cannot benefit from someone from their group holding power (Weghorst and Lindberg 2013; Horowitz 2017). If this is the case, then it is likely that groups such as the Coloured community are more likely to be swing voters because while they tend to align with the 
Democratic Alliance, the DA is not necessarily a 'Coloured party' in the sense that it is not explicitly and exclusively working for or run by members of the Coloured community (Ferree 2011). However, given that Coloureds do tend to support the DA (with some variation, see Habib and Naidu 1999), this study considers the DA to be the Coloured community's preferred party. ${ }^{4}$ Therefore, I hypothesize the following, which is a test of the racial census logic:

Hypothesis 1: Coloured voters are more likely to be swing voters than Black or White voters.

We should also expect that those who have a weaker racial identity are less likely to be influenced by race when deciding for whom to vote (Harris 2018). It is likely the case that if an individual does not primarily identify in racial or ethnic terms, she is less likely to be influenced by her racial or ethnic identity when deciding how to vote (Bratton et al 2012, McLaughlin 2007, Conroy-Krutz 2009). Similarly, those who do not feel close to their racial group's political party are also less likely to vote along racial lines. More generally, a large literature argues that weaker partisan attachments reduce consistent party support at the ballot box (i.e. Bartels 2000, Campbell et al 1960). Taken together, it should be expected that although individuals' racial identities do suggest they should vote a certain way, for some voters, the lack of attachment to the party that represents their group likely reduces the surety around voting for the group's party. Therefore, I hypothesize the following:

\footnotetext{
${ }^{4}$ Coloured support is of course more nuanced than presented here (i.e. Coloureds in the Western Cape tend to support the DA at higher rates compared to elsewhere in the country), but for our purposes here, I focus on the general tendencies of groups, which tends to be the approach of racial census arguments.
} 
Hypothesis 2: Individuals who do not primarily identify in racial terms are more likely to be swing voters.

Hypothesis 3: Individuals who are less attached to their group's party are more likely to be swing voters.

It is important to note that I do not hypothesize specifically regarding the role of partisanship independent of race because in practice in South Africa, it is extremely difficult to empirically separate the effects of race and partisanship. Therefore, I rather investigate the effect of racial-partisanship alignment. ${ }^{5}$ This is also a more direct test of the racial census argument, which this article seeks to critique, because it accounts for the ways in which race shapes partisan alignments.

Cohort effects are also key in new democracies. As younger generations no longer have direct experience living under former oppressive regimes, the electorate is less attached to the former divisions in society and fewer voters are attached symbolically to former liberation movements (Mattes 2012). In South Africa, a number of scholars have argued and found empirical support for the claim that voting behavior of the 'Born Free' generation is much less predictable than older generations, whose preferences are driven by the apartheid past (Mattes 2012; Kotze and Prevost 2015). Therefore, individuals from the born free generation should be more likely to be swing voters because their symbolic attachment to the ANC as liberator or the DA as the voice of the white minority (or a

\footnotetext{
${ }^{5}$ Further, when coding partisanship purely as the party one identifies with, closeness to the ANC, but not to the DA, reduces the probability that one will be a swing voter. Clearly ANC partisanship has an effect on swing voter status regardless of race, but, given this coding, it is difficult to know how race influences partisanship and swing voter status.
} 
holdover from apartheid) are weaker and thus they more readily consider voting for alternative parties:

Hypothesis 4: The 'Born Frees' are more likely to be swing voters than older generations.

If race is less important for some voters and the traditional political divisions are less salient for younger voters, then it is possible that other considerations may drive vote choice. If voters do not rely on race/identity or historical party heuristics (e.g. ANC as liberator), then a party's performance in office may play an important role especially in terms of corruption and patronage (Lodge 2014; Duncan 2015; Southall 2016) but also in terms of change in governance outcomes, e.g. reduction in crime. ${ }^{6}$ More generally, even if race and party play a key role in determining vote choice in a given context, those who are swing voters are more likely to be influenced by incumbent performance because by definition swing voters are less beholden to a single party and thus are more open. I therefore hypothesize the following:

Hypothesis 5: Individuals who assess the ANC's performance as poor are more likely to be swing voters.

If a voter has more friends and family who support a single party, then they are less likely to be swing voters. Network theories argue that as an individual's social network becomes more homogenous, we should expect him/her to be more likely to vote in accordance with a 'typical' member of the network's group (see Nieuwbeerta and Flap 2000). Even if race, policy, or cohort effects as discussed above drive people to change

\footnotetext{
${ }^{6}$ These expectations are in line with the broader literature on rational voting based on performance records (i.e. Miller and Wattenberg 1985).
} 
their vote, if individuals are surrounded by people who support a single party, then they may not swing at all but rather vote with the crowd (Green et al 2002, Ichino and Nathan 2013; Shulz-Herzenberg 2014):

Hypothesis 6: Individuals not embedded in a partisan community/network are more likely to be swing voters.

Swing voters may also be characterized by class (Seekings and Nattrass 2005, Mattes 2015), education (Weghorst and Lindberg 2013), policy preferences (Bratton et al 2012), urban residency (Ferree et al 2009), local development and public goods (Ferree et al 2009, Weghorst 2013), gender (Paret 2018), and ethnic identities (Horowitz 2017, Ferree et al 2009). While these are not the core theoretical focus of the study, the analysis below does control for these drivers of vote choice.

In addition to these hypotheses, the study investigates the degree to which these same variables influence the way in which swing voters vote. I do not propose hypotheses in this regard because, by definition, swing voters' choices are hard to predict. However, it is worth understanding what drove swing voters' decisions in 2016 to gain insight into how swing voters might behave in upcoming elections.

\section{Survey Data and Empirical Strategy}

To test the above hypotheses, I use original survey data from an exit poll of the 2016 local elections. The survey was conducted with 1,100 respondents in 42 polling stations across 25 wards in Tshwane Municipality. Wards and polling stations were selected randomly while stratifying on racial composition (from the 2011 census) and percent vote share for the ANC and DA (from the 2014 national election results). This ensures that the research team surveyed both homogenous and diverse areas as well as swing and strong hold areas. 
The resulting sample is then representative of the municipality. The sample included urban, suburban, township, and rural wards within the municipality.

Tshwane Municipality was chosen for a number of reasons. First, racially it is largely a microcosm of the country. While not matching the ethnic demography exactly, nearly all groups in terms of race, ethnicity, religion, class, etc. are present in large numbers in the municipality (with the exception of Indian voters). Therefore, while the survey is not nationally representative, the demography of Tshwane does maximize the study's generalizability with regards to the rest of the country, with the caveat that relative group sizes in a locality clearly play an important role in vote choice (Ichino and Nathan 2013). However, of course, Tshwane is unique ${ }^{7}$ and one should be cautious to apply these findings to, for example, rural municipalities in the North Cape or Kwa-Zulu Natal or even to party stronghold urban municipalities.

Second, Tshwane was a key swing municipality in the 2016 elections, which makes it an ideal case for understanding individual swing voters. The other candidate municipalities included Johannesburg and Nelson Mandela Bay. However, prior to election day, the ANC, while under threat in Johannesburg, was not expected to lose its majority there, but it was nearly certain to lose its majority in Nelson Mandela Bay. Tshwane, on the other hand, was extremely difficult to predict. The uncertain outcome in Tshwane is key not only for obtaining a sample of swing voters but also because it likely means respondents are giving more honest reports of their vote choice (they are less likely to simply report they voted for the expected winner because the winner was highly uncertain).

\footnotetext{
${ }^{7}$ Tshwane municipality did see a number of violent protests in the run-up to the elections regarding the imposition of an ANC mayoral candidate that many people disliked, which further illustrates it uniqueness.
} 
Further, Johannesburg is unique in many ways because it is the economic center of the country, and Nelson Mandela Bay does not offer the same degree of ethnic and racial diversity as Tshwane. Therefore, Tshwane was the ideal municipality for this study.

To uncover the profile of swing voters and determine which party swing voters are most likely to support, I use linear probability models. Each model includes a number of control variables (detailed below) and predict either swing voter status, or voting for one of the three main parties (ANC, DA, and EFF). The results below are robust to estimating logit regression and, for the vote choice analysis, to estimating multinomial logit regressions; see the online appendix for this analysis. I have chosen to present the linear probability model because it is the most straightforward model and provides easily interpretable coefficients. This analysis is purely correlational and does not facilitate a causal interpretation; however, this analysis is important because it allows us to see who is shifting the balance of power in South Africa's democracy.

The key dependent variable used to determine swing voter status is changes in respondents' reported vote choice from the 2014 to the 2016 elections. The survey asked respondents how they voted that day (2016 local elections) and asked them to recall how they voted in the 2014 national elections. The questions from the survey were: 'You just cast your ballot, can you please tell me, which party did you vote for?' and 'Which party did you vote for in the 2014 national elections?'. The questions were separated on the survey by about 25 questions. I then coded as one anyone who reported voting for two 
difference parties (or abstained in 2014 and voted in 2016) and all others as zero; respondents with a value of one on this variable are the swing voters. ${ }^{8}$

There are of course limitation in comparing national and local vote choice as research shows that decision making processes may be different in different types of elections (Harris et al 2018) and that voters are more willing to support opposition parties in local elections (Koepke and Ringe 2006). In some ways, comparing vote choice in the 2014 national and 2016 local elections may be comparing two different things. However, comparing the preferences of voters across South Africa's 2014 and 2016 elections does have some precedence (Paret 2018). Further, it is less reliable to ask respondents to remember how they voted in the previous local elections, which took place five years prior; Further, electoral dynamics changed significantly from the 2011 to the 2016 local elections with the emergence of the EFF party, currently the third largest party in parliament, in 2013. Therefore, comparing 2011 and 2016 is problematic given the party choice set changed. And finally, although local and national elections are in fact different, many saw the 2016 elections as a referendum on the national ANC government, which suggests that voters may, at least to some extent, be voting with both national and local concerns/orientations in these local elections.

\section{Results}

I first present descriptive data regarding which parties voters are swinging to and from. I then present data that investigates the effects of race and cohort on swing voting as these

\footnotetext{
${ }^{8}$ Only $8 \%$ of the survey respondents did not reveal how they voted in the 2016 elections; therefore, bias due to non-response is likely limited. Those who did not reveal their preference are more likely to be white, less educated, less embedded in partisan networks, and have lower assessments of the ANC's performance. The model controls for these variables.
} 
are key variables suggested in the literature. I then turn to a more rigorous multi-variate regression analysis to present a profile of swing voters and determine what drives swing voters to vote for the ANC, DA, and EFF.

\section{Who is a Swing Voter and Which Way do They Swing?}

In the sample, $34 \%$ of respondents reported changing their vote from the 2014 to the 2016 elections. This is quite large given the common perception that South African voters are locked into parties in large part due to racial and ethnic identities. Table 1 reports the direction that voters swung. The first column in Table 1 indicates the party that respondents voted for in the 2014 National Elections and row headings indicate the party respondents voted for in the 2016 Local Elections. The cells report the percent of respondents who voted for each combination of parties. The off-diagonal cells report swing voters while the principle diagonal reports the non-swing voters. The biggest change from 2014 to 2016 is that most swing voters are those who left the ANC (13\% of all swing voters), returned after abstaining in 2014 (another 13\% of swing voters), or swung toward the EFF (12\% of all swing voters). It is also clear form the table that those who left the ANC tended to favor the EFF over the DA.

In Tshwane municipality, the survey data estimates that $26 \%$ of swing voters swung toward the ANC, $28 \%$ swung toward the DA, and 32\% toward the EFF. Therefore, swing voters moving between the three largest parties accounts for $86 \%$ of all swing voters. This also suggests that the resulting change in leadership in Tshwane municipality, if in fact it was driven by swing voters, was largely driven by those who changed their vote to the EFF given that roughly equal proportions of swing voters swung toward the ANC and the DA. It is important to note that this exit poll data, given that all respondents voted, is unable to 
determine if abstention of ANC supporters is a driving factor in the ANC's loss of its majority in the municipality. However, this descriptive analysis does suggest that a viable, non-white alternative party (the EFF) ${ }^{9}$ likely played a role in the ANC's loss of Tshwane Municipality.

\section{$<$ Table 1 about here>}

The vote choice literature, the media, and South African electoral experts all suggest that race and cohort (e.g. born frees) influence swing voter status. First, according to racial census logic, Black and White South Africans should be relatively unlikely to change their vote due to strong attachments to the ANC and DA, respectively while Coloured and Indian South Africans should be relatively more likely to swing. The data only bears out these expectations in part. The second column in Table 2 reports the percent of each group that changed their vote between 2014 and 2016, the third column reports the percent of swing voters from each group, and the remaining column reports the percent of each group's swing voters that swung to the ANC, DA, and EFF in 2016. Table 2 shows that $64 \%$ of the Indian sample report changing their vote from 2014 to 2016 (only 13 Indian respondents in the sample). However, Black respondents reported changing their vote at higher rates than Coloured respondents, and Black respondents make up $79 \%$ of swing voters in the sample. This is likely an indicator of the weakening stance of the ANC given corruption scandals, the appeal of a viable alternative party in the EFF for Black voters,

\footnotetext{
${ }^{9}$ I characterise the EFF as a viable non-white alternative to the ANC as it and the ANC are the only black parties in Parliament with more than 5\% of the vote. It is not viable in the sense that it can defeat the ANC but rather that it is a party black voters feel they can support if they are unhappy with the ANC and/or are unwilling to vote for a 'white' party as many perceive the DA to be.
} 
and the steady solidifying of the Coloured community as a core constituency of the DA (despite the DA not being an exclusively Coloured party).

Now turning to cohort effects, I investigate the arguments that those who came of age after apartheid should be less attached to any party given that they lack the struggle attachment to the ANC and may be less likely to view the DA as a white party (Ferree 2011, Mattes 2012). I divide the sample into 'born frees' and the four other cohorts identified by Mattes (2012). He divides the cohorts by the degree to which they experienced apartheid. He defines cohorts by the year in which they 'reached their politically formative years', which is defined as 16 years old (137). Mattes (2012) identifies the following cohorts: pre-apartheid (turned 16 before 1948), early apartheid (turned 16 between 1948 and 1960), grand apartheid (turned 16 between 1961 and 1975), struggle generation (16 between 1976 and 1996), and born free (turned 16 after 1996). The survey does not contain any respondents in the pre-apartheid cohort (84 years of age or older at the time of the survey). As expected, the born frees are much more likely to swing: $38 \%$ of born frees in the sample changed their vote and they constitute $65 \%$ of the swing voters in 2016 (these statistics only include born frees who were at least 20 in 2016: those who could vote in 2014). Interestingly, born frees seem to nearly equally swing toward each of the three main parties.

\section{$<$ Table 2 about here>}

These initial results suggest that 1) Black voters may be among the most willing to swing especially when there is a viable alternative 'Black' party (the EFF) and 2) born frees are indeed more likely to swing. Further, race may not be a good indicator of which way an individual may swing. The born frees are not only more likely to swing, but it is 
also extremely difficult to determine which way they will swing, which suggests that the born frees are truly a wild card in the elections. However, I now turn to a more rigorous analysis to determine if these trends hold when controlling for other key drivers of the swing vote.

\section{Correlates of Swing Voting}

To systematically investigate the correlates of the swing voter in South Africa's 2016 elections, I estimate a linear probability regression model that predicts swing voter status. This analysis tests for the effect of the above-hypothesized factors on the likelihood of being a swing voter. The model includes controls for a number of additional variables. I operationalize the hypothesized variables as follows.

To detect the effect of race, the analysis not only looks at the effect of racial identity (Hypothesis 1; white and coloured dummies are included in the model with black as the reference category; no Indian respondents are included in the models given the very small sample size), but it also considers the effect of primarily identifying in racial terms (Hypothesis 2). The survey asks respondents, in an open-ended question, how they primarily identify themselves, ${ }^{10}$ and I code for whether or not each respondent indicated their racial identity in response to this question (ID Racially). As discussed above, it may not be racial group membership but rather whether or not an individual identifies racially that matters for determining swing voter status.

\footnotetext{
10 The exact wording was: "People identify themselves in a variety of different ways; how do you identify yourself?" $23 \%$ identified in religious terms, $22 \%$ in racial terms, $11 \%$ in ethnic terms, $10 \%$ in terms of nationality (i.e. South African), and $9 \%$ in terms of gender. Less than $8 \%$ identified in terms of a single other identity such as occupation, class, education, region, etc.
} 
To test Hypothesis 3, the model includes the Close to Party variable, which takes on a value of one if respondents indicate that they do feel close to the party that best represents their group (ANC for Black and DA for Coloured and White). This variable is based on the conventional partisanship question that asks first if the respondent feels close to a party and then asks which party.

I use the above cohort (born free is the reference category) dummy variables to test Hypothesis 4, which predicts that born frees will be more likely to swing.

To test Hypothesis 5, which predicts that those with lower assessments of the ANC's performance will be more likely to swing, the survey asks each respondent to assess the ANC in terms of how well it has benefited the respondent's race group and reduced crime, unemployment, and corruption. Responses (on a three-point scale: poor, fair, good) are averaged across the four categories and then standardized to range from zero to one (ANC Performance) with higher values indicating a more positive evaluation. I also construct an identical measure for DA performance as a control variable.

To measure the effect of partisan networks and to test Hypothesis 6, the survey asked each respondent whether or not most of their friends and family also support the party they voted for in the 2016 local elections (the question piped in the name of the party the person indicated voting for earlier in the survey). I then coded Co-Partisan Network as one if most of the respondent's friends and family members support the respondent's preferred party.

The model also controls for a number of additional variables. The model includes a dummy variable for whether or not the respondent primarily identifies in ethnic terms (the variable is constructed in the same manner as the ID Racially variable). To control for 
education, I divide the sample into those who did not finish high school, finished high school, and those who completed more than high school (the reference category is those who did not finish high school). The model also controls for whether or not the respondent lives in a rural or urban area. This variable was coded by the enumerator based on the type of area in which the polling station was located.

To measure the effect of policy, I use a question in the survey that asked respondents to choose between two statements regarding the best way to reduce crime. One statement reflected the ANC's approach (community watch) and the other reflected the DA's approach (a stronger police force/presence) as stated in their party manifestos without identifying in the survey the party that endorsed it. I then code for whether or not each respondent agreed with the policy of the party most readily associated with their group (ANC for Black and DA for Coloured and White). The variable Support Policy takes a value of one if the person supports their group's party's stance on crime reduction.

Given space limitations, the survey was only able to ask one question regarding policy rather than a battery of policy preferences. I chose this particular policy because crime is an extremely important issue in much of South Africa, but at the same time respondents are less likely to be aware of the different stances each party has taken on crime relative to that of economic issues, for example. Therefore, focusing on crime facilitates a measure of alignment between voter and party without clearly revealing each party's approach, which is necessary to avoid respondents simply agreeing with the policy stance that their party supports. Therefore, the analysis is better able to separate the effects of partisanship and policy. 
In addition, to address the importance of patronage and/or service delivery, the model controls for whether or not the respondent's area has received a development project in the last year. The model also controls for local racial diversity (using a ward-level measure of racial fractionalization, which is a Herfindahl index identical to ELF but racerather than ethnic-based), gender, employment status (dummy variable, in which one is employed and zero is unemployed), and ethnic dummy variables. The model also controls for whether or not the respondent has a sense of linked fate - the sense that one's own success/livelihood is tied to that of the group - with his/her group. ${ }^{11}$ I do not report the coefficients for these variables as they are largely insignificant; the coefficient estimates for these variables are available upon request.

$<$ Table 3 about here>

The results are reported in Table 3. Each column reports the results of an OLS model with standard errors clustered at the ward level. All models include the above mentioned key independent and control variables. The first model predicts swing voter status and directly tests the above hypotheses. The dependent variable takes the value of one if the respondent reported voting for a different party in 2014 than the party he/she reports voting for in the 2016 elections. The remaining models investigate the direction in which voters swing.

Hypothesis 1 predicts that groups without a co-racial party (e.g. Coloured voters) would be more likely to be swing voters than those that do have a party that represents their groups and its interests (e.g. Black and White voters). However, the analysis finds no evidence to support this case. The results of the first model reported in Table 3 ('Swing

${ }^{11}$ See the appendix for the questions used to measure linked fate. 
Voter') suggest that White and Coloured voters are 20\% and 16\% less likely to be swing voters than black respondents (the reference category). Although only white voters are significantly less likely to swing than black voters, and this result is only significant at the $10 \%$ level. Therefore, Coloured voters are not more or less likely to swing than Black voters and White voters are only marginally less likely to swing than Black voters. Therefore, there is no evidence that having a co-racial party makes one more or less likely to be a swing voter, which challenges the racial census hypothesis.

Now turning to Hypothesis 2, which predicted that individuals who do not primarily identify in racial terms would be more likely to be swing voters. The swing voter analysis indicates that this is precisely the case: those who primarily identify themselves in racial terms are significantly less likely, 8\% less likely, to change their vote between 2014 and 2016 than those who do not primarily identify in racial terms. In a racialized electoral system, those who do not primarily think of themselves in racial terms are more likely to swing. It is of course possible that voting for a party that is not associated with your racial group could reduce the salience of one's racial identity as elections have been found to influence how voters identity (Effiert et al 2010, Green 2018). These results suggest a key limitation of the racial census hypothesis: only if race is salient does it influence vote choice.

Not only attachment to one's racial group, but it is also likely that, as Hypothesis 3 predicts, individuals who are less attached to their group's party are more likely to be swing voters. Once again this prediction is upheld: those who report feeling close to their group's party (e.g. White voters feeling close to the DA), are $25 \%$ less likely to be swing voters, which suggests that the racial identities of parties do in fact prevent individuals from 
switching their vote. These results do suggest some support for racial census voting, but it is important to note that the size of the effect is on par with some other non-racial variables: partisan networks and some cohort effects. Therefore, the results suggest only limited support for racial census voting as other, non-racial variables have similar or larger effects. While unsurprising given past research, this is the first systematic evidence to suggest that the race-party-alignment does in fact help entrench the racial census character (that one's vote choice can be read from her racial identity) of South Africa's elections.

The results also confirm general expectations that Born Frees are more likely to be up for grabs (Hypothesis 4). All cohorts are significantly less likely to be swing voters compared to born frees (the reference category), and the size of the effect increases with age: the early apartheid generation is $34 \%$ less likely to change their vote compared to the born free generation, the grand apartheid cohort is $16 \%$ less likely, and the struggle generation is $14 \%$ less likely. Thus, it seems that the more experience voters have had with apartheid, the less likely they are to change their vote. Apartheid has clearly entrenched political preferences; however, in line with Mattes (2012), these results suggest that as time moves forward, South Africa's elections will see more swing voters and more volatility in vote choice.

The results also provide support for Hypothesis 5, which predicts that individuals who assess the incumbent ANC's performance as poor are more likely to be swing voters. Those who have a more positive assessment of the ANC's performance, on average, are $7 \%$ less likely to swing. Therefore, performance in office does in fact influence swing voter status to nearly the same degree as racial identification discussed above. 
And finally, the results indicate that individuals who are embedded in a partisan community are less likely to be swing voters (Hypothesis 6). Those who have more friends and family who support the same party they supported in 2016 are in fact $22 \%$ less likely to be swing voters. These results provide support for network theories of voter behavior and further question the racial census hypothesis.

In addition to these core results, the analysis finds that those who are more educated and those in urban areas are significantly less likely to be swing voters. However, a strong ethnic identity (i.e. Zulu, Xhosa, etc.), positive assessments of DA performance, and policy alignment with one's chosen party do not influence swing voter status. While not reported in the table, ethnic identity is also not a strong predictor of vote choice (only one of the eleven ethnic group dummies is significant).

We have therefore, identified swing voters in the 2016 elections as those who have weaker racial identities, weaker attachments to their group's party, are born free, have lower assessments of ANC performance, and have fewer friends and family who support their preferred party. Importantly, racial identity itself is not a clear predictor of swing voter status. Therefore, a variety of racial, partisan, performance, and network factors influence swing voter status. The results provide support for Hypotheses 2-6, but not Hypothesis 1, which indicates that swing voter status is more complex than racial group membership.

\section{What Drives the Swing Voter's Choice?}

While the above analysis has provided a sense of who swing voters are, the question still remains: how do these individuals vote? Of course, predicting swing voters' actually votes is inherently difficult; therefore, I focus on predicting what characteristics of swing voters predict voting for each of the three main parties. This analysis is reported in the 
remaining three columns of Table 3. These models are only run on the sub-sample of respondents who are swing voters, and thus the sample size is reduced by nearly threequarters. While limited in power, this analysis can provide key insights into which swing voters are attracted to which parties. As per the above discussion, most swing voters left the ANC for the EFF or came out of abstention to vote for the ANC or one of the two main opposition parties.

To determine which types of swing voters are attracted to which party, I estimate the same model from the first column of Table 3 with two adjustments in addition to the new dependent variables. First, given that no swing voters come from the Early Apartheid Generation, this variable is dropped from the vote choice analysis. Second, the model includes a dummy variable the indicates whether or not the respondent abstained from the 2014 elections. Given that abstainers make up nearly half of the swing voter sample, this is an important variable. This variable was omitted from the swing voter analysis above because, given that the survey is an exit poll, the sample does not include any respondents who voted in 2014 but abstained in 2016 or who abstained in both elections. Therefore, by definition all abstainers from 2014 are coded as swing voters and thus abstaining in 2014 would perfectly (and artificially) predict swing voter status. ${ }^{12}$ This problem does not exist when predicting the way in which individuals vote.

${ }^{12}$ Of course, voters may abstain for a variety of reasons (illness, unable to pay to travel to the polling station, etc.), but from over 20 qualitative interviews conducted throughout the research, it seems that many ANC supporters, in the face of corruption scandals, abstain rather than vote for another party which does suggest they are relatively more up for grabs than those ANC supporters who do turn out to vote. I therefore assume that most abstainers are in fact deciding to abstain and that those who were unable to vote for other reasons are relatively few. This seems reasonable given that the plurality (49\%) of those who abstained in 2014 voted for the ANC in 2016. 
The dependent variables in these analyses are binary indicators that take the value of one if the respondent reports voting for the relevant party. For example, the 'Vote ANC' variable takes the value of one if the respondent voted for the ANC in 2016 and zero otherwise. The results in the last three columns of Table 3 provide a number of interesting correlates of swing voter vote choice. These results are robust to estimating logit and multinomial logit models (see the online appendix for these results).

First, the way in which people primarily identify is key. Those who identify racially are significantly less likely to vote for the DA and significantly more likely to vote for the EFF, but they are not more or less likely to vote for the ANC. This is not unexpected given that the ANC officially takes a non-racial or post-racial stance, the DA actively tries to showcase its diversity and acceptance of all races, while the EFF clearly positions itself as a champion of the black cause. Therefore, those who have a strong racial identity and see the ANC's indifference and the DA's opposition to racialized politics are more attracted to the EFF, not attracted to the DA, and indifferent to the ANC. Interestingly though, Coloured and White swing voters are significantly more likely to vote for the EFF than black swing voters (but only at the $10 \%$ level). This seems odd, but may be explained by the very few Coloured and White respondents who supported the EFF in 2014. Therefore, there is a greater likelihood that such voters would be swinging toward the EFF. This interpretation is supported empirically by the survey data. While $8 \%$ of black respondents reported voting for the $\mathrm{EFF}$ in 2014 , less than $1 \%$ of white and $2 \%$ of coloured respondents report doing so. Further, even though a larger proportion of black respondents swung toward the EFF compared to coloured and white respondents, roughly equal proportions of black respondents swung toward the ANC, DA, and EFF. 
Now consider the effect of Co-Partisan Network, which is coded as one if the respondent reports that most of her family and friends support the party the respondent voted for in 2016; or in this case, given that the sample is restricted to swing voters, this variable measures whether or not most of the respondent's close acquaintances support the party he/she swung to in 2016 but did not support in 2014. Interestingly, those who have more friends and family who support the ANC are more likely to swing to the ANC, but if a person has more friends and family who support the DA, they are less likely to swing toward the DA (see the coefficients associated with Co-Partisan Network in the third model reported in Table 3). It is curious that individuals are actually less likely to swing to the DA when their friends and family also support the DA. Future research would do well to investigate why this is the case.

The coefficients across these three models for Close to Party suggest that attachment to the ANC among black voters prevents them from moving away from the ANC and toward the EFF. As a reminder, this variable is coded as one if black respondents feel close to the ANC and one if coloured or white respondents feel close to the DA. The results illustrate that those who feel close to their group's party are more likely to swing to the ANC and less likely to swing toward the EFF. This combination of results seems to suggest that if black voters are sufficiently close to the ANC, then they are likely to swing back to the ANC (after abstention or a brief moment of voting against the ANC) but not to the EFF, which is likely the most viable alternative for black voters. To support this interpretation, I re-estimated the ANC and EFF vote choice models on only the black population and the results are the same suggesting that closeness to the ANC does keep 
black swing voters from abandoning the ANC for the EFF. It is possible that as attachments to the ANC weaken, support for the EFF may strengthen.

It is also encouraging that party performance drives vote choice. The results show that those who have a positive assessment of the ANC's performance in office are more likely to swing toward the ANC and less likely to swing toward the DA. The opposite is true for those who positively assess the DA's performance. These results suggest that swing voters do consider party performance when deciding for whom to vote and that South African politics is in fact likely moving, ever so slowly, away from race-based politics.

And finally, the results indicate that abstainers from 2014 are significantly more likely to vote for the ANC in 2016. This fits with a narrative of ANC voters who would prefer to abstain when they cannot bring themselves to vote against the ANC and yet turn out to vote in hopes to ensure that the ANC is not removed from office in a competitive election.

To summarize, racial group membership does not predict how swing voters will swing, but the strength of their racial identity does: those who primarily identify themselves in racial terms are less likely to vote for the DA and more likely to vote for the EFF. Further,

closeness to the ANC prevents black voters from swinging toward the EFF, and swing voters are more likely to support the party they view as having a stronger performance record.

\section{Conclusion}

This paper has uncovered a swing voter profile for South Africa's 2016 local elections. This is important as it illustrates what types of voters are up for grabs in South Africa's elections. The ability to predict swing voters in elections is the crux of understanding the 
electoral process: swing voters often determine electoral victory, especially in such a close election as the Tshwane municipal elections. If we are able to identify and predict what motivates individuals to swing in elections, we can better understand what drives voters and what likely leads a party to victory. Is it policy? Is it generational? Is it changes in partisanship attachments? The results here suggest that each of these aspects plays a role in the South African context.

The results also illustrate which types of voters are moving beyond racial politics. The study finds that swing voters have weaker racial identities, weaker attachments to their racial group's party, are born free, have lower assessments of ANC performance, and have fewer friends and family who support their preferred party. Importantly, the results lend support to rational choice, partisanship, and network theories of voter behavior. These results paint the picture of a swing voter who is less influenced by racial, racial-partisan, and historical considerations and more influenced by performance records. While some identity variables do predict swing voter status, the results, taken together, suggest very limited support for racial census voting as other, non-racial variables have significant effects and Hypothesis 1 receives no empirical support. In addition, a more diverse political network also helps encourage swing voting: as South Africa continues to develop and integrate, which puts people of different backgrounds and political persuasions into direct contact, South Africans are more likely to swing vote in elections.

The results also suggests that swing voters in South Africa are the types of voters that lead to better government accountability because these voters are not beholden to racial identities, history, and how these factors dictate vote choice. These voters are more likely to consider performance and vote accordingly. What exactly leads individuals to break 
away from race-based voting is an important question that this study raises and which has been investigated elsewhere. For example, Harris (2018) suggests that social treatment influences how racial identities are constructed and in turn how weaker identities influence vote choice in South Africa.

In short, the findings that performance records, more politically diverse social networks, weaker racial identities, and born-free cohort membership are correlated with the swing vote suggest that more than race matters for this group of voters. For example, it is possible that a weaker racial identity opens voters up to consider policy performances, which is key for moving beyond race in elections. Future research would do well to more explicitly investigate this relationship.

While the results largely cast doubt in the veracity of the racial census hypothesis, the results also indicate that race still plays a key role in how swing voters actually vote: the extent to which swing voters racially identify determines, in part, which party they will support. The EFF has cornered the market on those swing voters who primarily identify in racial terms (the racialized swing voters). This suggests that party rhetoric and strategy do influence swing voters as the EFF has engaged in highly racially-charged campaigns and rhetoric. It is also interesting that while racial and race-based partisan attachments are less important for swing voters, racial attachments to the ANC do prevent some swing voters from supporting the EFF. Therefore, while race is less important for swing voters, it is not irrelevant.

These results also have important implications for understanding voting behavior in dominant party regimes beyond South Africa. The results suggest that as dominant regimes and especially liberation movements (e.g. Zanu-PF in Zimbabwe) age, the 
importance of historical attachments and social divisions may begin to wane. The results in South Africa suggest that as voters move away from historical allegiances and beyond traditional social cleavages, the dominant party regime - which has often established its dominance through these allegiances/cleavages - will begin to lose its popular support and dominance. Why exactly voters move past history and social cleavages is beyond this study, but it is an important line of inquiry. Equally important, performance records are also likely a motivating factor for people to withhold their support form liberation movements as they fail to deliver.

More generally, these results can also speak to what types of voters are potentially swing in Africa more generally: those for whom social identities are less salient. While the current study focused on race and found no effects of ethnicity, it is possible that the dominant social cleavage in a society acts in similar ways as race in South Africa. For example, ethno-linguistic identities constitute the key political cleavage in Kenya; therefore, while ethno-linguistic identities were not significant in South Africa, they may be in a place like Kenya. It is possible that Kenyan voters who do not primarily identify in ethnic terms are more likely to swing, which is in line with Horowitz's (2017) findings. Future research should test the role of the strength of ethnic identification on swing voter status in other contexts to further test the role of social identity in African politics.

\section{References}

Bartels, L. 2000. 'Partisanhip and Voting Behavior, 1952-1996. American Journal of Political Science 44, 1:35-50..

Bratton, Michael, Ravi Bhavnani and Tse-Hsin Chen. 2012. 'Voting Intentions in Africa: Ethnic, Economic, or Partisan?' Commonwealth and Comparative Politics 50, $1: 27-52$. 
Campbell, A., P. Converse, W. Miller, and D. Stokes. 1960. The American Voter. University of Chicago Press.

Carlson, E. 2015. 'Ethnic voting and accountability in Africa: A choice experiment in Uganda'. World Politics.

Chandra, K. 2004. Why Ethnic Parties Succeed: Patronage and Ethnic Head Counts in India. Cambrigde University Press.

Conroy-Krutz, Jeffrey. 2009. 'Who are Africa's (Non) Ethnic Voters? Evaluating Theories on the Salience of Ethnicity in African Electoral Politics' Presented at the APSA Annual Meeting, September 2009.

de Kadt, Daniel. 2017. 'Voting then, Voting now: The Long Term Consequences of Participation in South Africa's First Democratic Election' Journal of Politics, 72, 2.

Dimock, Michael, April Clark and Juliana Menasce Horowitz. 2008. 'Campaign Dynamics and the Swing Vote in the 2004 Election.' In The Swing Voter in American Politics. The Brookings Institute: Washington D.C.

Duncan, J. 2015. The Rise of the Securocrats: the case of South Africa. Auckland Park: Jacana.

Eifert, Benn, Edward Miguel and Daniel N. Posner. 2010. 'Political Competition and Ethnic Identification in Africa,' American Journal of Political Science 54, 2:494510.

Eldridge, Matt and Jeremy Seekings. 1996. 'Mandela's Lost Province: The African National Congress and the Western Cape Electorate in the 1994 South African Elections,' Journal of Southern African Studies 22, 4: 517-540.

Everatt, David. 2016. 'The Era of Ineluctability? Post-Apartheid South Africa Afrer 20 Years of Democratic Elections' Journal of Southern African Studies 42, 1: 49-64.

Ferree, Karen E. 2011. Framing the Race in South Africa: The Political Origins of Racial Census Elections. Cambridge University Press.

Ferree, Karen, Clark Gibson and Barak Hoffman. 2009. 'Explaining the African Vote.' Working Paper, University of California San Diego.

Giliomee, H. \& C. Simkins. 1999. The Awkward Embrace: one-party domination and democracy. Cape Town: Tafelberg.

Green, Donald, Bradley Palmquist, and Eric Schickler. 2002. Partisan Hearts and Minds: Political Parties and the Social Identities of Voters. Yale University Press: New 
Haven, Conn.

Green, Elliott. 2018. 'The Politics of Ethnic Identity in Sub-Saharan Africa,' Presented at the APSA Annual Meeting, Boston, September 2018.

Grootes, Stephen. 2013. S.A. Politics Unspun. Two Dogs, Johannesburg.

Grootes, S. 2016. 'Things fall apart: downward pressure as ANC government loses its grip', Daily Maverick, 24 October. <http://www.dailymaverick.co.za/article/201610-24-things-fall-apartdownward-pressure-as-anc-government-loses-itsgrip/\#.WBonC6I9YnJ>, accessed 9.27.2018.

Habib, Adam and Sanusha Naidu. 2006. 'Race, Class and Voting Patterns in South Africa's Electoral System: Ten Years of Democracy' Africa Development 31, 3: 81-92.

Habib, Adam and Sanusha Naidu. 1999. 'Elections '99: Was there a Coloured and Indian Vote' Politikon 26, 2:189-199.

Harris, Adam. 2018. 'At the Borders of Identity: Racial Identity Construction and the Limits of Bloc Voting' Presented at the APSA Annual Meeting, Boston, September 2018.

Harris, Adam and Erin Hern. 2018. 'Taking to the Streets: Protest as an Expression of Political Preference in Africa', Comparative Political Studies, forthcoming.

Harris, Adam S., Kristen Kao and Ellen Lust. 2018. 'The Determinants of Local and National Vote Choice: Evidence from a Conjoint Experiment.' Presented at the Annual Governance and Local Development Conference, Gothenburg Sweden, June 2018.

Horowitz, D. L. 1985. Ethnic Groups in Conflict. California University Press: Los Angeles.

Horowitz, Jeremy. 2017. 'Ethnicity and the Swing Vote in Africas Emerging Democracies: Evidence from Kenya.' British Journal of Political Science.

Ichino, Nahomie and Noah L. Nathan. 2013. 'Crossing the Line: Local Ethnic Geography and Voting in Ghana.' American Political Science Review 107, 2:344-361.

Koepke, J.R. and N. Ringe. 2006. 'The second-order election model in an enlarged Europe', European Election Politics 7, 3:321-46.

Kotze, Joleen S. and Gary Prevost. 2015. 'Born free - an assessment of political identity formation and party support of South Africa's first post-Apartheid generation' Africa Insight 44, 4: 142-168. 
Lodge, T. 2014. 'Neo-patrimonial politics in the ANC', African Affairs 113, 450:1-23.

Mattes, Robert. 2012. 'The 'Born Frees': The Prospects for Generational Change in Postapartheid South Africa', Australian Journal of Political Science 47, 1: 133-153.

Mattes, Robert. 2015. 'South Africa's Emerging Black Middle Class: A Harbinger of Political Change?' Journal of International Development 27:665-692.

Mattes, Robert and J. Piombo. 2001. 'Opposition Parties and the Voters in South Africa's General Election of 1999.' Democratization 8, 3:101-128.

Mayer, William G. 2007. 'The Swing Voter in American Presidential Elections.' American Politics Research 35(3):358-388.

Mayer, William G. 2008. The Swing Voter in American Politics. The Brookings Institute: Washington D.C.

Mayer, William G. and Ruy Teixeira. 2008. 'The State of the Discussion.' In The Swing Voter in American Politics. The Brookings Institute: Washington D.C.

McLaughlin, Eric S. 2007. 'Beyond the Racial Census: The Political Salience of Ethnolinguistic Cleavages in South Africa.' Comparative Political Studies 40, 4:435-456.

Miller, A. and M. Wattenberg. 1985. 'Throwing the Rascals Out: Policy and Performance Evaluations of Presidential Candidates, 1952-1980.' American Political Science Review 79(2): 359-372.

Nieuwbeerta, P. and H. Flap 2000. 'Crosscutting Social Sircles and Political Choice Effects of Personal Network Composition on Voting Behavior in The Netherlands.' Social Networks 22: 313-335.

Paret, M. 2018. 'Beyond Post-Apartheid Politics? Cleavages, Protest, and Elections in South Africa', Journal of Modern African Studies 56, 3:471-96.

Posner, D. 2005. Institutions and Ethnic Politics in Africa. Cambridge University Press.

Powell, G. Bingham and Guy D. Whitten. 1993. 'A Cross-National Analysis of Economic Voting: Taking Account of the Political Context' American Journal of Political Science, 37, 2: 391-414.

Przeworski, Adam. 2015. 'Acquiring the Habit of Changing Governments Through Elections' Comparative Political Studies, 48, 1:101-129.

Schulz-Herzenberg, Collette. 2014. 'The Influence of the Social Context on South African Voters.' Journal of Southern African Studies 40, 4:839-859. 
Seekings, Jeremy and Nicoli Nattrass. 2005. Class, Race, and Inequality in South Africa. Yale University Press: New Haven, Conn.

Shaw, Daron R. 2008. 'Swing Voting and U.S. Presidential Elections' In The Swing Voter in American Politics. The Brookings Institute: Washington D.C.

Southall, R. 2016. 'The coming crisis of Zuma's ANC: the party-state confronts fiscal crisis', Review of African Political Economy 43, 147:73-88.

Weghorst, Keith R. and Staffan I. Lindberg. 2013. 'What Drives the Swing Voter in Africa?’ American Journal of Political Science 57, 3:717-734.

Zaller, John. 2003. 'Floating Voters in U.S. Presidential Elections, 1948-2000.' In Studies in Public Opinion: Gauging Attitudes, Nonattitudes, Measurement Error, and Change. William E. Saris and Paul M. Sniderman (eds.). Princeton University Press. 


\section{Tables}

Table 1: The Direction of the Swing Vote: From the 2014 to 2016 Elections

\begin{tabular}{lcccc}
\hline \hline & ANC & DA & EFF & Other \\
\hline ANC & 40 & 4 & 7 & 2 \\
DA & 1 & 21 & 1 & 1 \\
EFF & 0.2 & 1 & 6 & 0 \\
Other & 1 & 1 & 1 & 1 \\
Abstained & 7 & 3 & 3 & 0.7 \\
\hline
\end{tabular}

Table 2: Race, Cohort, and the Swing Vote

\begin{tabular}{lccccc}
\hline \hline & $\begin{array}{c}\text { Percent } \\
\text { Swing }\end{array}$ & $\begin{array}{c}\text { Percent } \\
\text { of Swing }\end{array}$ & $\begin{array}{c}\text { Percent } \\
\rightarrow \text { ANC }\end{array}$ & $\begin{array}{c}\text { Percent } \\
\rightarrow \text { DA }\end{array}$ & $\begin{array}{c}\text { Percent } \\
\rightarrow \text { EFF }\end{array}$ \\
\hline Race & & & & & \\
Black & 37 & 79 & 10 & 8 & 14 \\
Coloured & 28 & 7 & 10 & 9 & 3 \\
Indian & 64 & 2 & 10 & 30 & 10 \\
White & 21 & 12 & 1 & 13 & 2 \\
\hline Age/Cohort & 0 & 0 & - & - & - \\
Early Apartheid & 0 & 8 & 12 & 32 & 20 \\
Grand Apartheid & 27 & 24 & 9 & 27 & 40 \\
Struggle Generation & 24 & 65 & 32 & 28 & 32 \\
Born Free & 38 & & & &
\end{tabular}


Table 3: OLS Regressions Predicting Swing Voter Status

\begin{tabular}{|c|c|c|c|c|}
\hline & Swing Voter & Vote ANC & Vote DA & Vote EFF \\
\hline Coloured & $\begin{array}{r}-0.159 \\
(0.105)\end{array}$ & $\begin{array}{r}-0.055 \\
(0.259)\end{array}$ & $\begin{array}{r}0.052 \\
(0.289)\end{array}$ & $\begin{array}{c}0.200 * \\
(0.114)\end{array}$ \\
\hline White & $\begin{array}{l}-0.196 * \\
(0.113)\end{array}$ & $\begin{array}{r}-0.437 \\
(0.296)\end{array}$ & $\begin{array}{r}0.306 \\
(0.318)\end{array}$ & $\begin{array}{c}0.192 * \\
(0.105)\end{array}$ \\
\hline ID Racially & $\begin{array}{l}-0.075 * * \\
(0.035)\end{array}$ & $\begin{array}{r}0.019 \\
(0.062)\end{array}$ & $\begin{array}{l}-0.154 * * * \\
(0.034)\end{array}$ & $\begin{array}{l}0.165 * * \\
(0.075)\end{array}$ \\
\hline Close to Party & $\begin{array}{l}-0.246 * * * * \\
(0.041)\end{array}$ & $\begin{array}{l}0.279_{* * *} \\
(0.091)\end{array}$ & $\begin{array}{r}0.057 \\
(0.082)\end{array}$ & $\begin{array}{l}-0.333_{* * *} \\
(0.076)\end{array}$ \\
\hline Early Apartheid & $\begin{array}{l}-0.343 * * * \\
(0.058)\end{array}$ & & & \\
\hline Grand Apartheid & $\begin{array}{l}-0.157 * * \\
(0.060)\end{array}$ & $\begin{array}{r}0.039 \\
(0.095)\end{array}$ & $\begin{array}{r}-0.003 \\
(0.112)\end{array}$ & $\begin{array}{r}-0.103 \\
(0.087)\end{array}$ \\
\hline Struggle Generation & $\begin{array}{l}-0.135 * * * \\
(0.039)\end{array}$ & $\begin{array}{l}-0.120 * \\
(0.059)\end{array}$ & $\begin{array}{l}-0.073 \\
(0.069)\end{array}$ & $\begin{array}{r}0.080 \\
(0.069)\end{array}$ \\
\hline ANC Performance & $\begin{array}{l}-0.072 * * \\
(0.032)\end{array}$ & $\begin{array}{l}0.118 * * \\
(0.046)\end{array}$ & $\begin{array}{l}-0.128 * * \\
(0.057)\end{array}$ & $\begin{array}{l}-0.068 \\
(0.066)\end{array}$ \\
\hline Co-Partisan Network & $\begin{array}{l}-0.218 * * * \\
(0.047)\end{array}$ & $\begin{array}{l}0.150 * * * \\
(0.033)\end{array}$ & $\begin{array}{l}-0.146 * * \\
(0.057)\end{array}$ & $\begin{array}{r}0.017 \\
(0.060)\end{array}$ \\
\hline ID Ethnically & $\begin{array}{r}-0.079 \\
(0.046)\end{array}$ & $\begin{array}{r}0.027 \\
(0.057)\end{array}$ & $\begin{array}{r}0.130 \\
(0.083)\end{array}$ & $\begin{array}{r}-0.112 \\
(0.069)\end{array}$ \\
\hline DA Performance & $\begin{array}{l}-0.001 \\
(0.028)\end{array}$ & $\begin{array}{l}-0.082 * * \\
(0.039)\end{array}$ & $\begin{array}{l}0.212 * * * \\
(0.062)\end{array}$ & $\begin{array}{l}-0.126 * \\
(0.072)\end{array}$ \\
\hline Completed High School & $\begin{array}{r}-0.010 \\
(0.045)\end{array}$ & $\begin{array}{r}0.007 \\
(0.061)\end{array}$ & $\begin{array}{r}0.007 \\
(0.077)\end{array}$ & $\begin{array}{c}0.101 * \\
(0.054)\end{array}$ \\
\hline More than High School & $\begin{array}{l}-0.108 * \\
(0.054)\end{array}$ & $\begin{array}{r}0.052 \\
(0.066)\end{array}$ & $\begin{array}{r}0.056 \\
(0.084)\end{array}$ & $\begin{array}{r}0.020 \\
(0.071)\end{array}$ \\
\hline Support Policy & $\begin{array}{r}0.009 \\
(0.031)\end{array}$ & $\begin{array}{r}0.027 \\
(0.033)\end{array}$ & $\begin{array}{l}-0.052 \\
(0.051)\end{array}$ & $\begin{array}{r}0.041 \\
(0.054)\end{array}$ \\
\hline Urban & $\begin{array}{l}-0.124 * * * \\
(0.033)\end{array}$ & $\begin{array}{r}-0.074 \\
(0.049)\end{array}$ & $\begin{array}{r}0.054 \\
(0.052)\end{array}$ & $\begin{array}{l}-0.049 \\
(0.049)\end{array}$ \\
\hline Abstained in 2014 & & $\begin{array}{l}0.253 * * * \\
(0.061)\end{array}$ & $\begin{array}{l}-0.026 \\
(0.061)\end{array}$ & $\begin{array}{r}-0.105 \\
(0.066)\end{array}$ \\
\hline Development Project & Yes & Yes & Yes & Yes \\
\hline Local Racial Diversity & Yes & Yes & Yes & Yes \\
\hline Male & Yes & Yes & Yes & Yes \\
\hline Employed & Yes & Yes & Yes & Yes \\
\hline Ethnic Dummies & Yes & Yes & Yes & Yes \\
\hline Linked Fate & Yes & Yes & Yes & Yes \\
\hline ID Ethnically & Yes & Yes & Yes & Yes \\
\hline Constant & $\begin{array}{l}1.173 * * * \\
(0.123)\end{array}$ & $\begin{array}{r}0.138 \\
(0.274)\end{array}$ & $\begin{array}{r}0.407 \\
(0.324)\end{array}$ & $\begin{array}{l}-0.015 \\
(0.179)\end{array}$ \\
\hline $\mathrm{R}^{2}$ & .24 & .45 & .26 & .32 \\
\hline $\mathrm{N}$ & 860 & 281 & 281 & 281 \\
\hline
\end{tabular}

Significance levels: $\quad *: 10 \% \quad * *: 5 \% \quad * * *: 1 \%$

Standard Errors Clustered at the Ward level 


\section{Online Appendix for:}

\section{Moving from race to performance-based politics: Swing voters in South Africa's 2016 local elections}

This online appendix reports result for two sets of additional models. The first analysis, presented in Table 4, is a set of models that estimate logit models that are identical (in terms of variables) to the OLS models presented in Table 3 of the paper. The second table in this appendix (Table 5) presents results from a multinomial logit model that predicts which party a swing voter will support (voting for the ANC as the reference outcome). The results are robust to these alternative estimation strategies.

Linked fate is measured using two survey questions: 'Do you agree or disagree with the following statement: I can only succeed socially, economically, and politically if the [respondent's racial group] as a whole succeeds socially, economically, and politically' and 'Do you agree or disagree with the following statement: If the [respondent's racial group] is diminished or harmed, then I am personally diminished/harmed as well'. To construct the variable, Linked Fate, I coded all respondents who agreed as one and disagreed as zero for each question. I then averaged these coded responses. 
Table 4: Logit Regressions Predicting Swing Voter Status

\begin{tabular}{|c|c|c|c|c|}
\hline & Swing Voter & Vote ANC & Vote DA & Vote EFF \\
\hline \multirow[t]{2}{*}{ Coloured } & -0.868 & 0.074 & 0.508 & $12.597_{* * *}$ \\
\hline & $(0.662)$ & $(2.374)$ & $(1.367)$ & $(1.463)$ \\
\hline \multirow[t]{2}{*}{ White } & -1.156 & $-5.023 *$ & 1.661 & $12.348_{* * * *}$ \\
\hline & $(0.750)$ & $(2.696)$ & $(1.527)$ & $(1.442)$ \\
\hline \multirow[t]{2}{*}{ ID Racially } & $-0.456 *$ & 0.263 & $-1.072 * * *$ & $1.094_{* * *}$ \\
\hline & $(0.235)$ & $(0.725)$ & $(0.274)$ & $(0.369)$ \\
\hline \multirow[t]{2}{*}{ Close to Party } & $-1.228 * * *$ & $2.629 * * *$ & 0.374 & $-2.348 * * *$ \\
\hline & $(0.185)$ & $(0.748)$ & $(0.525)$ & $(0.550)$ \\
\hline \multirow[t]{2}{*}{ Grand Apartheid } & $-0.898 * *$ & 0.458 & -0.003 & -0.669 \\
\hline & $(0.376)$ & $(1.218)$ & $(0.603)$ & $(0.725)$ \\
\hline \multirow[t]{2}{*}{ Struggle Generation } & $-0.785 * * *$ & $-1.593 * *$ & -0.512 & 0.536 \\
\hline & $(0.220)$ & $(0.790)$ & $(0.382)$ & $(0.451)$ \\
\hline \multirow[t]{2}{*}{ ANC Performance } & $-0.382 *$ & $1.117_{* * *}$ & $-0.919 * *$ & -0.261 \\
\hline & $(0.196)$ & $(0.404)$ & $(0.401)$ & $(0.456)$ \\
\hline \multirow[t]{2}{*}{ Co-Partisan Network } & $-1.127_{* * *}$ & $1.580_{* * *}$ & $-1.039_{* * *}$ & -0.009 \\
\hline & $(0.226)$ & $(0.384)$ & $(0.384)$ & $(0.381)$ \\
\hline ID Ethnically & $\begin{array}{r}-0.470 \\
(0.306)\end{array}$ & $\begin{array}{c}0.835 * \\
(0.468)\end{array}$ & $\begin{array}{l}1.138 * * \\
(0.540)\end{array}$ & $\begin{array}{l}-0.969_{* *} \\
(0.456)\end{array}$ \\
\hline DA Performance & $\begin{array}{l}-0.004 \\
(0.167)\end{array}$ & $\begin{array}{l}-0.841 * * \\
(0.427)\end{array}$ & $\begin{array}{l}1.699_{* * *} \\
(0.460)\end{array}$ & $\begin{array}{l}-0.984 * * \\
(0.474)\end{array}$ \\
\hline Completed High School & $\begin{array}{r}-0.069 \\
(0.266)\end{array}$ & $\begin{array}{r}-0.267 \\
(0.596)\end{array}$ & $\begin{array}{r}0.158 \\
(0.473)\end{array}$ & $\begin{array}{l}0.664 * * \\
(0.332)\end{array}$ \\
\hline More than High School & $\begin{array}{l}-0.605 * \\
(0.317)\end{array}$ & $\begin{array}{r}0.534 \\
(0.636)\end{array}$ & $\begin{array}{r}0.511 \\
(0.476)\end{array}$ & $\begin{array}{r}0.099 \\
(0.448)\end{array}$ \\
\hline Support Policy & $\begin{array}{r}0.042 \\
(0.183)\end{array}$ & $\begin{array}{r}0.453 \\
(0.284)\end{array}$ & $\begin{array}{l}-0.355 \\
(0.339)\end{array}$ & $\begin{array}{r}0.160 \\
(0.376)\end{array}$ \\
\hline Urban & $\begin{array}{l}-0.697 * * * \\
(0.182)\end{array}$ & $\begin{array}{r}-0.301 \\
(0.454)\end{array}$ & $\begin{array}{r}0.408 \\
(0.308)\end{array}$ & $\begin{array}{l}-0.395 \\
(0.331)\end{array}$ \\
\hline Abstained in 2014 & & $\begin{array}{l}2.313 * * * \\
(0.817)\end{array}$ & $\begin{array}{l}-0.389 \\
(0.356)\end{array}$ & $\begin{array}{l}-0.713 * \\
(0.415)\end{array}$ \\
\hline Development Project & Yes & Yes & Yes & Yes \\
\hline Local Racial Diversity & Yes & Yes & Yes & Yes \\
\hline Male & Yes & Yes & Yes & Yes \\
\hline Employed & Yes & Yes & Yes & Yes \\
\hline Ethnic Dummies & Yes & Yes & Yes & Yes \\
\hline Linked Fate & Yes & Yes & Yes & Yes \\
\hline ID Ethnically & Yes & Yes & Yes & Yes \\
\hline \multirow[t]{2}{*}{ Constant } & $3.739 * * *$ & -4.270 & -0.719 & $-14.649_{* * *}$ \\
\hline & $(0.801)$ & $(2.999)$ & $(1.704)$ & (1.819) \\
\hline Pseudo $\mathrm{R}^{2}$ & 0.20 & 0.50 & 0.25 & 0.30 \\
\hline $\mathrm{N}$ & 848 & 280 & 280 & 270 \\
\hline
\end{tabular}


Table 5: Multinomial Logit Regression Predicting Swing Voter Status (Base Outcome = Vote ANC)

\begin{tabular}{|c|c|c|}
\hline & Vote DA & Vote EFF \\
\hline Coloured & $\begin{array}{r}0.734 \\
(2336)\end{array}$ & $\begin{array}{r}0.222 \\
(2964)\end{array}$ \\
\hline White & $\begin{array}{c}5.260 * \\
(2.786)\end{array}$ & $\begin{array}{c}5.053 * \\
(2.713)\end{array}$ \\
\hline ID Racially & $\begin{array}{r}-0.998 \\
(0.580)\end{array}$ & $\begin{array}{r}0.569 \\
(0.890)\end{array}$ \\
\hline Close to Party & $\begin{array}{l}-2.269 * * \\
(0.901)\end{array}$ & $\begin{array}{r}-3.928 \\
(0.938)\end{array}$ \\
\hline Grand Apartheid & $\begin{array}{r}1.249 \\
(1.059)\end{array}$ & $\begin{array}{r}0.196 \\
(1.418)\end{array}$ \\
\hline Struggle Generation & $\begin{array}{l}2.063 * * * \\
(0.790)\end{array}$ & $\begin{array}{l}2.775 \text { *** } \\
(0.781)\end{array}$ \\
\hline ANC Performance & $\begin{array}{l}-1.503 * * * \\
(0.544)\end{array}$ & $\begin{array}{l}-0.916 * * \\
(0.444)\end{array}$ \\
\hline Co-Partisan Network & $\begin{array}{l}-2.278 * * * \\
(0.468)\end{array}$ & $\begin{array}{l}-1.647 * * * \\
(0.434)\end{array}$ \\
\hline All other Controls & Yes & Yes \\
\hline Constant & $\begin{array}{r}1.956 \\
(3.316)\end{array}$ & $\begin{array}{r}0.446 \\
(2.558) \\
\end{array}$ \\
\hline $\mathrm{N}$ & 241 & 241 \\
\hline
\end{tabular}

